\title{
The Value of a Coaching Internship: From the Students' Perspective 從學生的角度看教練實習的價值
}

\author{
David BARNEY
}

Brigham Young University

Marie BONE

Brigham Young University

Kelsey HIGGINSON

Ohio State University

Teresa LEAVITT

Brigham Young University

\begin{abstract}
For many college students completing their education, an internship is a requirement for graduation, the same is true for students that want to become coaches. Interview data from 21 college seniors (10 males \& 11 females) at the conclusion of their coaching internship revealed that interns generally found their internship successful and valuable in their preparation to becoming a coach. During the interviews, the interns expressed the importance of communications with the athletes, parents, administrators and the public, the heavy time commitment of coaching, and the importance of relationships. The interns also, expressed a desire to mentor an intern someday when they are coaching.
\end{abstract}

Keywords: coaching, internships, coaching behaviors

\section{Introduction}

A college student's education takes on many forms of learning, which might include: class time, lectures, note taking, study groups, taking quizzes and exams etc. Another form of the student's education can come in the form of an internship in their chosen field of study. An internship can be the most important component of a student's preparation (Stratta, 2004). For many students, the internship is their first exposure to the actual work environment, giving them a chance to better understand the workings of their field of employment (Diffenbaugh, Murray, \& Zakrajasek, 2011). The practice of the internship is also found in the field of coaching. Smith (2008) has stated that many coaching education programs have adopted an internship experience as part of the curriculum. The purpose of a coaching internship is to provide the student with a realistic experience in the coaching profession including accompanying responsibilities (Barney, 2013 \& Smith, 2008).

Literature specific to the coaching internship has examined the internship experience in various college coaching education programs. Diffenbaugh, Murray, and Zakrajsek (2011) surveyed 53 college students preparing to coach at the high school level. The results of this study found that college students felt the internship helped bridge their classroom knowledge to real world experiences. Students were exposed to duties such as administrative responsibilities coaches face on a 
daily basis, communication with athletes, staff, parents and administrators, actual coaching of the athletes during practices and games, and a multitude of other experiences. The researchers also concluded from the data that the coaching internship has the potential to provide the interns with the opportunity to increase both content knowledge and skills to coach.

A second study dealing with coaching internships examined the effective experiences, attitudes and perceptions of abilities of female coaching interns following the internship (Weiss, Barber, Sisley \& Ebbeck, 1991). After a year long coaching internship participants were interviewed to better understand their experiences. The researchers divided the interview data into four headings: 1) positive aspects of the coaching internship, 2) negative aspects of the coaching internship, 3) perceived coaching strengths, and 4) perceived coaching weakneses. Positive aspects of the coaching internship included working with athletes, developing coaching skills, social support and fun. Negative aspects of the coaching internship were excessive time demands, low perceived coaching competence, negative working relationship with athletes, and overemphasis on winning. Perceived coaching strengths were communication skills, teaching skills, discipline and balance of work and fun, while perceived coaching weaknesses were lack of sport-related knowledge and skills, lack of leadership qualities, poor planning and management and poor injury-prevention and maintainance skills. The researchers concluded that the coaching internship should be structured as a learning laboratory where interns can develop coaching skills along side good coaches.

The reflective cycle theory framework was used for this study, which Gibbs (1988) explains is reflection viewed as a process with the anticipated outcome to prepare the practitioner for action. For this study the coaching intern was asked questions about their internship thus causing them to reflect upon their internship. This was done with the hope that these reflections would shape their coaching behaviors and practices when they are coaching their own team.

The National Standards for Sport Coaches (NASPE, 2006) is one tool at a coach's disposal to assist in positively affecting interns' experiences as they participate in their coaching internship. The purpose of these standards is to "provide direction for coaching educators, sport administrators, coaches, athletes and their families, and the public regarding the skills and knowledge that coaches should posses" (NASPE, 2006). The standards are divided into eight domains. Those eight domains are: 1) Philosophy and Ethics, 2) Safety and Injury Prevention, 3) Physical Conditioning, 4) Growth and Development, 5) Teaching and Communication, 6) Sport Skills and Tactics, 7) Organization and Administration, and 8) Evaluation. As mentioned these standards are to assist coaches, and while interns are not mentioned as a targeted audience for these standards, because they can be considered a coach, these standards would also apply to the coaching intern. For example, a couple of the sub-headings within the domains of the standards that are applicable to coaching interns are to "provide a positive learning environment that is appropriate to the characteristics of the athletes and goals of the program." Another applicable sub-headings for coaching interns is to plan and implement daily practice activities that maximize time on task and available resources. These along with the other standards can help coaches as they mentor coaching interns during the internship experience. The internship can be a foundational experience that exposes them to a number of experiences that will affect and influence the intern throghout their coaching career. Thus, the purpose of this study was to better understand the value of a coaching internship through the students' voices.

\section{Methods}

\section{Participants}

For this study 21 college seniors (10 males \& 11 females) completing their coaching internship participated in this study. The participants coached in basketball, football, swimming and volleyball, and ranged in age from 21 to 30 years of age. The participants for this study were from a private university located in the western United States. The student-body population of the university is approximately 30,000 students.

\section{Interview Format}

The researchers reviewed the coaching education literature for interview questions to pose to the coaching interns at the conclusion of their internship (Weiss, Barber, Sisley \& Ebbeck, 1991; Gilbert \& Trudel, 2005; Smith, 2008; Diffenbaugh, Murray, Zakrajsek, 2011). Following this review, the researchers identified 11 questions to include in the interns's concluding interview. 
To establish content validity, three reseachers reviewed the interview questions for clarity and understanding. For reliability, the instrument was pilot-tested on nine pre-coaching interns, who did not participate in the study.

\section{Procedures}

Following approval from the institutional review board (IRB) of the university, one of the researchers explained the study to the coaching interns, seeking their participation in the study. All interns were assured that their voluntary decision to participate or not participate in the study would not affect their grade in their internship. At the conclusion of the coaching internship, the interns scheduled a time to participate in their concluding interview. The interview took approximately 45 minutes to complete, with all interviews being audio recorded. After the interviews were completed, one researcher transcribed the interviews. The researchers read and reread the data until common themes became evident (O'Sullivan \& Tsangariou, 1992; Mueller \& Skamp, 2003). A qualitative thematic content analysis was utilized to determine relevant concluding interview themes. Sarvela and McDermott (1993) have defined qualitative thematic content analysis as "any technique for making inferences by objectively and systematically identifying specific characteristics of messages."

\section{Results}

Themes and phrases from the 11 interview questions were compiled (Table 1). A summary of the intern's responses to the 11 interview questions follows. The results of these interviews indicate that despite some challenges, the internship was overall positive and productive.

\section{Were you able to effectively communicate with the athletes?}

The interns generally felt that they were able to effectively communicate with the athletes they coached. They felt that as the internship progressed throughout the season their communication improved. Steve said, "Especially as the internship went on, they paid attention when I was talking." Joe said, "I talked to them faceto-face. I did not text them." Jane stated, "We had very open communications. I was able to speak with the athletes."Did you have valuable interactions with your athletes?
The interns felt they had valuable interactions with their athletes. Some of their interactions were about what the athletes experienced outside practices and games. Kevin said, "I got to see players with family members that were struggling with all sorts of problems (e.g. alcohol \& drugs). Because I saw that I had to deal with it. I wanted to be available to the players." Susan said, "We had team meals. I got to know the players better", and Betty stated, "Some of them opened up to me. I had their trust. Their trials were pretty tough at home."

\section{In your opinion, did the athletes respect you in your role as a coach?}

Here again, the interns felt they were respected in their role as an intern coach. For this specific interview question one group that showed respect to the intern coaches were the coaches (head and assistants), this in turn impacted the athletes being respectful towards the intern coaches. Frank stated, "The head coach treated me as an equal. This translated with the players." Erin said, "It started from the beginning when the coaches showed me respect. The players following along with the coaches, they knew I was serious." Another factor that helped the intern coaches gain respect was his or her own personal participation on high school and university athletic teams. Steve mentioned, "... because I have a background in college football they respected what I said." Mark stated, "It helped coming from the local university and having a strong swimming background. They would listen to me."

\section{How was your communication with the coaches?}

For this interview question the interns felt the overall communication with the coaches was good. However, some of the interns felt they were able to have better or more frequent communication with the assistant coaches. Mary said, "The head coach was hard to effectively communicate with. She had a lot going on. So I found that going to the other coaches were easier to talk with." Stephani said, "The head coach was open to all suggestions. I am not sure she took my suggestions seriously." In addition, Susan said, "Talking to the head coach was a little rough." 
How effective were you in teaching sport specific skills?

The interns felt their ability to teach sport specific skills depended on the level (varsity or junior varsity (JV)) with which they worked. Intern coaches reported that working with varsity athletes limited the teaching to sport specific skills. Betty said, "There wasn't much teaching on the varsity level. It was hard at this level. Nick stated, "At the beginning I worked with the JV. I worked with them on their defense. When I worked with the varsity, not as much." Others like Joe said, "I was able to teach my drills I have been taught. I was able to explain it. I got in the water with the athletes."

\section{How involved were you with practice and game planning?}

Many of the interns had experiences with planning practices but limited experiences planning for games. Generally speaking, the interns stated, "Practice planning I did a lot" or "I would go over the practice plan with the head coach." Despite involvement with practice planning, it was reported that, "I didn't do much game planning."

\section{How much were you allowed to teach and coach?}

From this interview question it is evident the interns had many opportunities to teach and coach in their specific sports. Devin said, "I had free reign. Even to the extent of adjusting technique. The coaches were comfortable with it." Jane stated, "She gave me free reign on what I wanted to do." Moreover, Jeff shared, "At our high school, I did a lot. I was a member of the staff. I didn't feel like and intern."

\section{If you were a head coach, would you want to work with an} intern?

For this interview question all the interns stated they would mentor an intern if they were a head coach. Frank stated, "Yes. Because how I was treated, I would love to mentor someone. I would love to give back." Susan said, "I would love having an intern. It would give me more hands to help the team. More opportunities to learn." In addition, Mary said, "Honestly treat them the way I was treated. Get them involved and listen to their perspectives."
What three things can you take from your internship?

Interns identified many things they took from their experience as a coaching intern. The three repeated experiences the interns took from their internship were: 1) the time involved in coaching, 2) to get involved early (be proactive), and 3) relationships. Intern responses dealing with the time involved coaching included, "A person needs to understand that you will put in a lot of time",and "Coaching is an investment, you have to put all of you in it. You can't be half and half." Statements regarding early involvement were, "Don't be afraid to step up and get involved" and "Show up for the first practice ready to coach." Statements regarding relationships advised: "Develop a positive relationship with your athletes, parents and administrators" and "Develop relationships of trust."

In your opinion, has this internship prepared you to be a coach?

All the interns stated that their internship did prepare them to become a coach. The interns said, "I got a good idea of what it takes. What I need to do to continue to learn and grow", "Definitely, a lot more beneficial than sitting in a class", and "A valuable component for me. Big part in my development."

\section{Has this internship solidified your decision to continue coaching?}

Once again, the interns positively responded to this interview question. The following responses affirmed the interns' desire to continue coaching after their graduation, as well as at what level they would like to coach. For example, Nick stated, "One of the reasons I came back to school was I loved coaching. I had some hesitations and this experience answered it for me. I can do this." Frank said, "I think when I couldn't go to practices it hit me that I really liked this and wanted to do it." And finally, Jane said, "After the season was over, I was ready to start coaching again. I really enjoyed it (coaching)." 


\section{Discussion}

The purpose of this study was to better understand the value of the coaching internship through the students' voice. Interview results generally indicated that the coaching internship was valuable for the students. The themes that came from the interview questions emphasized the importance the coaching internship plays in developing college students as they begin their career as a coach

Interview responses confirmed that coaching is a time intensive experience. Many of the interns learned that there is a large time commitment (Weiss, Barber, Sisley \& Ebbeck, 1991). Because of the time commitment required the interns stated, "You will not get paid a lot for the time you put in." Another intern said, "The time that is involved for coaches is much. But it is worth it." When the interns expressed their thoughts about the time commitment required as a coach, it was not negative. It is likely many of the interns that participate in their internship were successful high school athletes and had a successful experience in the sport they played. As former athletes they came to practice and played in games. Now that they are interns they see that there is more to coaching than showing up for practice and the games. There is scouting, watching film, working with parents and administrators, getting officials for games, and a multitude of other responsibilities. All require a coach's time. Weiss, Barber, Sisley and Ebbeck (1993) studied the positive and negative experiences of a season long internship for interns. As part of the positives that came from the yearlong internship, interns felt that they developed their coaching skills, the social support was good for the interns and the experience was fun. The internship gave the intern a realistic picture of the time commitment a coach has.

Another valuable lesson learned from the internship was the importance of good communication with the athletes. This applied to the athletes, the head coach and other coaches, the parents, and administrators. In the National Standards for Sport Coaches: Quality Coaches Quality Sports (2006), two standards emphasize the importance of communications. Standard 25, states "Use effective communication skills to enhance individual learning, group success and enjoyment in the sport experience." For example, one of the benchmarks for this standard is, "Use terminology of the specific sport necessary to communicate intended outcomes and activities with athletes and coaches." Standard 31 states, "Be involved in public relation activities for the sport program." A benchmark for this standard is, "Communicate policies and ongoing program activities to athletes, staff, parents/guardians, administrators, and or the public." When looking at both standards closer, the intent of these standards emphasizes how important good communication can be in helping an athlete improve, to promote your athletes and program to the parents and public. These standards emphasize that good communication can greatly benefit the athlete, parents, the public and administrators. As one of the interns in this study stated, "The head coach has to effectively communicate with them (athletes, other coaches, parents and administrators) all."

One of the last experiences the interns found valuable during their internship was the relationships aspect. This included earning the athletes respect, how to work with the athletes, and working with the coaches. Weiss, Barber, Sisley and Ebbeck (1991) found a positive aspect of the coaching internship was the satisfaction they received working with the athletes. The interns found the interactions with the athletes positive and enjoyable. One intern stated, "We were friends and yet... I don't know, it's hard to explain. I just loved it because I was making a difference, not just athletically but as far as their life." For this study the interns also felt that the relationships they created and had were a very positive aspect of their internship. One of the interns stated, "I felt I created a good strong bond with the athletes. I didn't have a buddy-buddy relationship." Another intern stated in reference to having a good relationship with the athletes, "I think I did. In building that rapport with them. They could come to me with questions they had." When the interns talked about their relationship with the coaches, one intern said, "It was a strong point with my internship. I could talk to all of them (the coaches)." Because of the relationships, the interns had with the athletes, they felt it translated into respect for each other. One intern stated, "I was impressed with how respected I was." Another intern said, "The athletes would listen to me when I would talk to them during and after drills." 
From these experiences and others, the interns felt their internship was of value. As Smith (2008) has said the internship is designed to provide students with a semester of practical coaching field experience under the supervision of a school or community professional. These interns were able to participate in practical coaching field experiences, along with many other experiences. Coaching internships are important and have value for students that want to become coaches. One of the interns summed up the value of the internship when he said, "I felt I had a calling to coach. This internship has solidified my decision to coach."

The findings from this study strongly align with previous research dealing with internships in coaching. Internships are valuable and important in preparing college students to become coaches. Universities that have coaching education programs need to continue this valuable aspect of a students' education. For those universities that may not have the internship component, they should seriously consider implementing the internship. The internship has the possibility of better preparing college students for the rigors of coaching.

\section{Limitations to the Study and Future Research}

It is important to note possible limitations of this study. Because the participants came from one university this may not allow for a representative sampling of university students of all universities or in other geographic regions. Thus, the generalizability of the findings is limited.

One suggestion for future research would be to replicate this study, but investigate different interns on a yearly basis at the same school with the same coach doing their internship. This could provide evidence of effective internship experiences in those settings and provide further support for the importance of placing interns in appropriate placements. Another potential future research project would be to expand this study to examine the experiences of coaching interns at other universities to address and increase the generalizability of these findings.

\section{References}

Barney, D. (2013). A coach's example is important: Coaching education can play a part. Journal of Coaching Education, 6(1), 106-110.

Dieffenbach, K.D., Murray, M., \& Zakrajsek, R. (2011). The coach education internship experience: An exploratory study. International Journal of Coaching Science, 5, 3-25.

Gibbs, G. (1988). Learning by Doing: A Guide to Teaching and Learning Methods. (Oxford, FE Unit Oxford Polytechnic).

Gilbert, W.D., \& Trudel, P. (2005). Learning to coach through experience: Conditions that influence reflection. The Physical Educator, 62(2), 32-43.

Mueller, A., \& Skamp, K. (2003). Teacher candidates talk: Listen to the unsteady beat of learning to teach. Journal of Teacher Education, 54(5), 428-440.

National Association for Sport and Physical Education. (2006). Quality coaches, quality sports: National standards for sport coaches $\left(2^{\text {nd }}\right.$ ed.). Reston, VA: Author.

O'Sullivan, M., \& Tsangaridou, N. (1992). What undergraduate physical education majors learn during a field experience. Research Quarterly for Exercise and Sport, 63(4), 381-392.

Sarvela, P.D., \& McDermott, R.J. (1993). Health education evaluation and measurement: A practitioner's perspective. Madison, WI: WCB Brown \& Benchmark.

Smith, J.L. (2008). The value of internships in a NCACE accredited coaching education program. Journal of Coaching Education, 1(1), 1-9.

Stratta, T. (2004). The needs and concerns of students during the sport management internship experience. The Journal of Physical Education, Recreation, \& Dance, 75(2), 25-29. 
Weiss, M.R., Barber, H., Sisley, B.L., \& Ebbeck, V. (1991). Developing competence and confidence in novice female coaches: II. Perceptions of ability and affective experiences following a season-long coaching internship. Journal of Sport \& Exercise Psychology, 13, 336-363.

\section{Correspondence}

David Barney, Ed.D.

Associate Professor

Brigham Young University

249G SFH Provo, Utah 84602, U.S.A>

(801) $422-6477$

(801) 422-0930 FAX

Email: David_Barney@byu.edu

Table 1. List of Coaching Interns Interview Themes from Interview Questions

\section{Coaching Interns Themes}

Were you able to effectively communicate with the athletes?

- They paid attention when I was talking.

- I was able to speak with the athletes from the very beginning.

- I talked to them face to face. I did not text them.

Did you have valuable interactions with your athletes?

- We had team meals. I got to know them better.

- I created a good strong bond with the athletes.

- $\quad$ The interactions were different yet productive.

In your opinion, did the athletes respect you in your role as a coach?

- I was impressed with how respected I was. It was a great environment.

- I didn't have any athletes give me any attitude.

- It started from the beginning when the other coaches showed me respect.

How was your communication with the coaches?

- The head coach was hard to effectively communicate with.

- We were all able to collaborate.

- $\quad$ They respected my opinion.

How effective were you in teaching sport specific skills?

- For most part they got what I was trying to teach.

- There wasn't much teaching at the varsity level.

- $\quad$ As far as teaching the basics I did well.

How involved were you with practice and game planning?

- Practice planning I did a lot.

- Game planning kind of involved.

- $\quad$ Not much of both.

How much were you allowed to teach and coach?

- $\quad$ A lot. I coached everyday.

- I had free reign.

- Not a ton. Very rarely. 